\title{
Vaucheria species (Xanthophyceae) of the Kraków-Czestochowa Upland (Poland)
}

\author{
K. Wolowski ${ }^{1}$
}

Keywords : Vaucheria, the Kraków-Czestochowa Upland, Poland, spring, stream, river, pond, soil.

The distribution and ecological data base of Vaucheria bursata, V. frigida, V. geminata, V. racemosa, V. erytrospora, V. canalicularis, and V. debaryana occurring in streams of the Kraków-Czestochowa Upland (Poland) are provided.

Les espèces de Vaucheria (Xanthophyceae) provenant du Plateau de Cracovie-Czestochowa (Pologne)

Mots-clés : Vaucheria, Plateau de Cracovie-Czestochowa, Pologne, source, ruisseau, rivière, étang, sol.

Des données sur la distribution et l'écologie des espèces Vaucheria bursata, V. frigida, V. geminata, V. racemosa, V. erytrospora, V. canalicularis, V. debaryana dans les rivières du plateau de Cracovie-Czestochowa sont présentées.

\section{Introduction}

The-Kan-Czestochowa Upland (K-CZU) is an integral region of Central-European Uplands and belongs to Malopolska Upland (Southern Poland) (Fig. 1.). It is the most interesting and picturesque area of Poland to which belong six Jurassic Landscape Parks and Ojców National Park. In streams of the K-CZU Vaucheria species form macroscopic dark green velvety mats on.damp.soil, on rocks in flowing water, or occasionally on woolly mats floating on the surface of ponds.

Information concerning taxa occurrence in this region is scarce (Wolowski 2001), usually documented on occasionally collected materials (Gutwiński 1884, 1895, Starmach 1939, Turoboyski 1956, Kadlubowska 1964, Uherkovich 1970, Siedlecka-Binder 1967, Dratnal 1977) and without any description or illustration. From the K-CZU some information about the occurrence of $V$. geminata and $V$. bursata can be found in Gutwiński $(1884,1890,1895)$. A precise study by Amirowicz (1981a, b, 1986) gives information concerning 11 taxa that occurred in seven streams (Bedkówka, Kobylan-

\footnotetext{
1. Polish Academy of Sciences, W. Szafer Institute of Botany, Department of Phycology, ul. Lubicz 46, PL-31-512 Kraków, Poland.
}

ka, Pradnik, Raclawka, Szklarka, Dlubnia, and Szreniawa) and the River Vistula ; there are also notes about the occurrence of two in the Kluczwoda stream by the present author (1992).

The study on the occurrence of Vaucheria was carried out from 1994-1998 mainly in running waters, fishponds, and on wet soil.

\section{Material and methods}

The distribution of macroscopic thalli was observed just over a year from October 1993 to December 1994 along the whole length of the Kobylanka stream (Fig. 2). Materials from Kluczwoda, Czernka and Raclawka streams were collected only a few times; the samples from the rest of streams were collected only once. The material was taken from the surface of the muddy bottom and stones, and also pieces of wood sunk in the water. Parts of the thalli were transported in vivo in plastic, $25 \mathrm{ml}$ jars, while the rest were preserved in a 2.5-4.5\% solution of formaldehyde. Live thalli were kept in dishes or small glass jars (with a small amount of water from the stream) near a north-facing window. After two or three weeks, when the sex organs were developed and localized on filaments just below the water surface, the species could be identified. Zeiss Jena and Optiphot 2 Nikon light microscopes were used for the studies. 


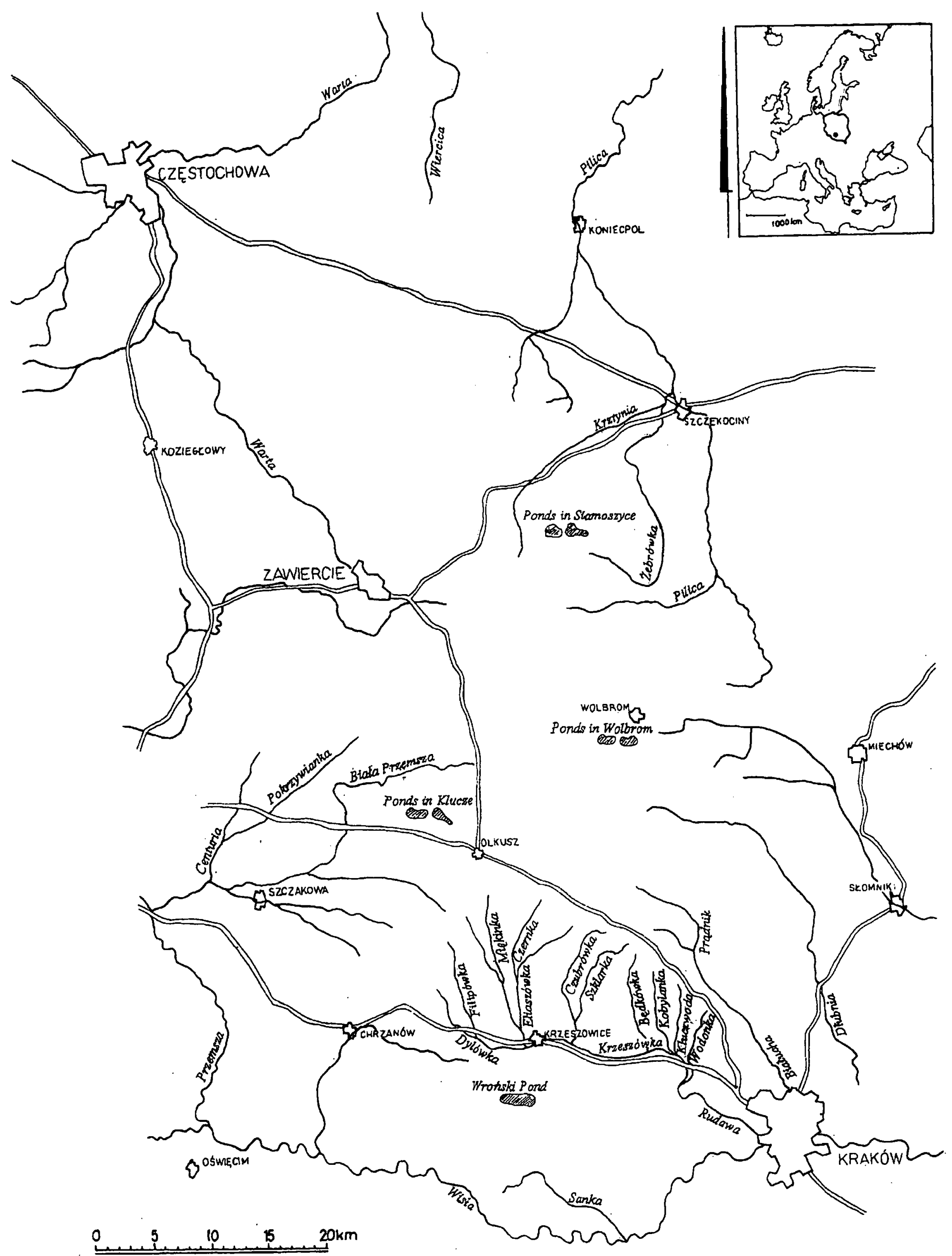

Fig. 1. Map of the study area, distribution of sites in Kraków-Czestochowa Upland.

Fig. 1. Carte géographique et distribution des stations dans la région du plateau de Cracovie-Czestochowa. 


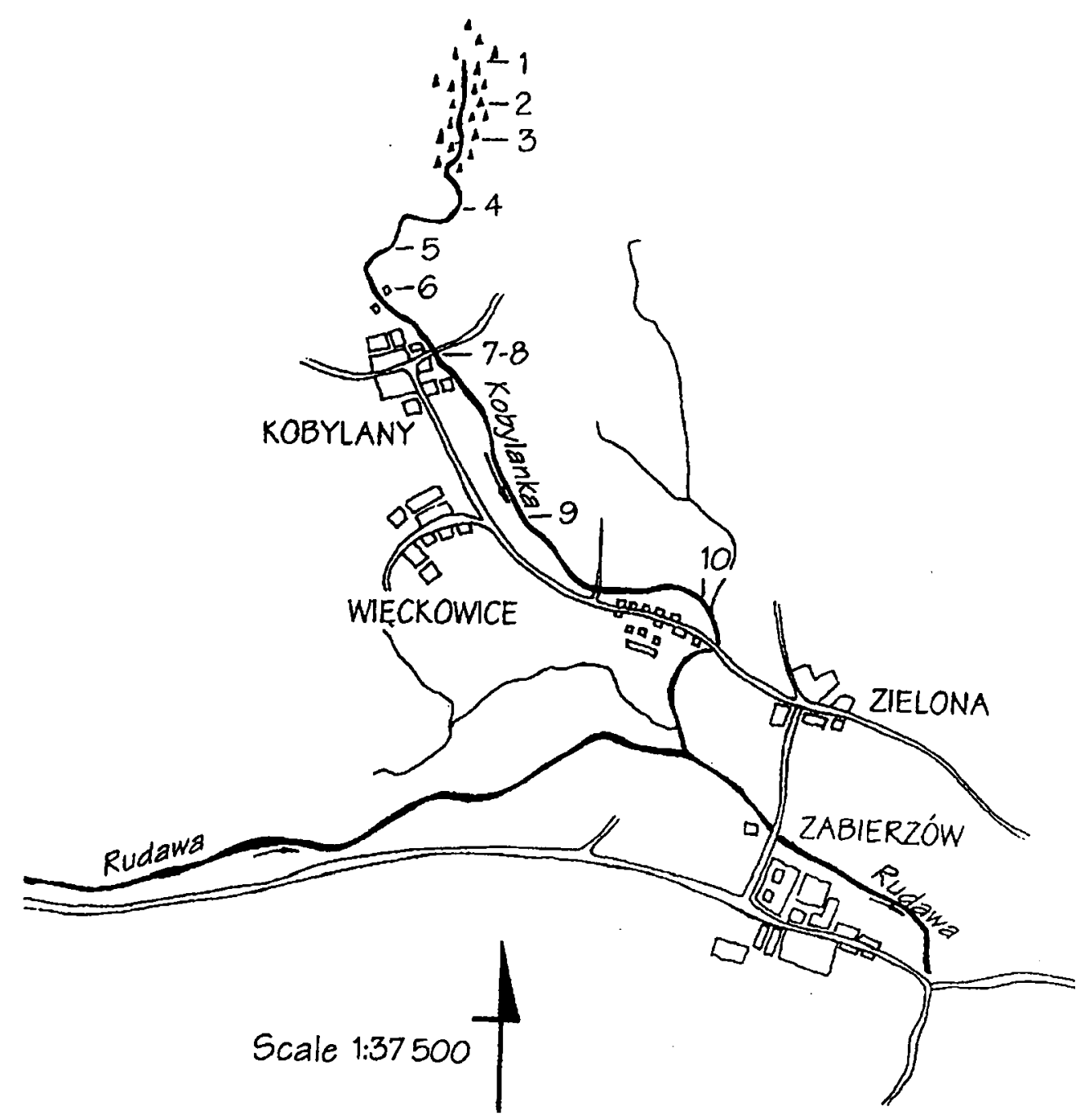

Fig. 2. Distribution of sites in Kobylanka stream.

Fig. 2. Distribution des stations dans le ruisseau Kobylanka.

\section{Results}

Among 35 observed sites, Vaucheria was found in 32 places but only seven taxa were identified. The identification was made according to Chrystiansen 1956, 1973, 1987, Rieth (1980) and Starmach (1972). Information on reports of the occurrence of each species in the Kraków-Czestochowa Upland is given below. Data on the world distribution of species and their habitats were obtained from the cited monographs, separate papers, and from the Iconotheca of Algae collected in the Department of Phycology of the Institute of Botany, Polish Academy of Sciences.

\subsection{Sectio Corniculatae}

Subsectio Sessiles

- V. bursata (O.F. Müller) Agardh (= Vaucheria sessilis (Vaucher) De Candolle f. sessilis (Determination after Chrystiansen 1973, 1969). Figs: 1-3, 22.
Vegetative filaments $75.5-100 \mu \mathrm{m}$ in diam. Monoecious. Oogonium longitudinal, egg-shaped to oval, sessile, 59-75 $\mu \mathrm{m}$ in diam., 82-97 $\mu \mathrm{m}$ long. Antheridium tubular, hooked at the anterior end some times twisted, $29-32 \mu \mathrm{m}$ in diam. Oospores $55.5-70 \mu \mathrm{m}$ in diam., 75-82.5 $\mu \mathrm{m}$ long, completely fill the oogonium. Found in : Bedkówka, Bialucha, Brynia, Czernka, Czubrówka, Eliaszówka, Filipówka, Kluczwoda, Kobylanka, Kobylica, Pokrzywianka, Pradnik, Sanka, Saspówka, Szklarka streams and Wronski pond near Tenczynek.

In the K-CZU previously reported from : Mydlniki fishponds (Starmach 1939), spring of Szklarka stream (Skalna 1973), Bolechowicki stream (Amirowicz 1981a, b, 1986) and in Kluczwoda stream (Nawral 1993). In Poland reported as very common.

Cosmopolitan ; widespread ; poor indicator of water quality (Sladecek \& Sladeckova 1996) 
Note : According to Rieth (1980 : p. 58), V. bursata is a synonym of $V$. sessilis (Vaucher De Candolle).

Subsectio Racemosae

- V. frigida (Roth) Agardh (= Vaucheria terrestris sensu Götz ) (Determination after T. Christensen 1969). Figs. 4-7, 21.

Vegetative filaments $43-100 \mu \mathrm{m}$ in diam. Monoecious. Oospores spherical, dark, $65-100 \mu \mathrm{m}$ in diam., 85-151 $\mu \mathrm{m}$ long. Antheridium twisted, $14-15 \mu \mathrm{m}$ in diam. Found in Kluczwoda and Kobylanka streams.

In the K-CZU previously reported from Bolechówka stream (Amirowicz 1981b). In Poland known from a pond in Lagiewniki near Lódz (Kadlubowska 1964) and from the salt marshes near Leczyca (Plinski 1973). The report of Gutwinski (1895) concerns the Ukraine (formerly Polish territory).

General distribution : Europe, Asia, North America, Australia and North Africa ; common ; good indicator of oligosaprobic water (Sladecek \& Sladeckova 1996).

Note : According to Rieth (1980) V. frigida (Roth) Agardh is a synonym of $V$. terrestris sensu Götz.

- Vaucheria geminata (Vaucher) De Candolle (Determination after Rieth 1980). Figs. 8-9, 23.

Vegetative filaments $105-128 \mu \mathrm{m}$ in diam. Monoecious. Oogonium $70 \mu \mathrm{m}$ in diam., $80-100 \mu \mathrm{m}$ long. Oospores 65-67 $\mu \mathrm{m}$ in diam., 70-80 $\mu \mathrm{m}$ long, completely filling of the oogonium. Antheridium tubular, hooked at the anterior end or spirally twisted, ca. $30 \mu \mathrm{m}$ in diam. Found in : Bedkówka, Brynia, Czernka, Czubrówka, Eliaszówka, Filipówka, Kluczwoda, Kobylanka, Krztynia, Pokrzywianka, Saspówka and Szklarka streams.

In the K-CZU previously reported from the Kluczwoda stream (Wolowski 1992). In Poland reported also from the River Vistula near Swiniary (Amirowicz 1986), Rivers Warta, and Widawka (Zelazna-Wieczorek 1998).

General distribution : Europe, Asia, North America and North Africa ; common ; medium indicator of water quality (Sladecek \& Sladeckova 1996).

- V. racemosa (Vaucher) De Candolle (= Vaucheria walzii Rothert) (Determination after T. Christiansen 1969). Figs. 10-14, 24.

Vegetative filaments $97-120 \mu \mathrm{m}$ in diam. Monoecious. Oogonium egg-shaped, $65-73 \mu \mathrm{m}$ in diam., 82.3-93 $\mu \mathrm{m}$ long, usually 2-7 located on stalks under the antheridium. Antheridium spirally twisted. Found in : Czernka, Filipówka, Kobylanka, Mienkinka and Sanka streams.
In the K-CZU previously reported from : Bolechowicki (Amirowicz 1981a, b) and Kluczwoda streams (Wolowski 1992). In Poland reported also from Ochaby carp pond (Mrozinska 1957) and Rivers Warta and Widawka (Zelazna-Wieczorek 1998).

General distribution : Europe, Asia, North Africa ; common.

Note : According to Rieth (1980: p. 96)., V. racemo$s a$ is a synonym of $V$. walzii.

- Vaucheria erythrospora T. A. Christensen 1956 (= $V$. hamata sensu Götz f. salina Rieth). (Christiansen 1987). Figs. 15-16, 27.

Vegetative filaments $40-65 \mu \mathrm{m}$ in diameter. Monoecious. Oogonium rounded at the base, empty at the apical part. Oospores $45-54.5 \mu \mathrm{m}$ in diam, redishbrown. Antheridium twisted, $17-20 \mu \mathrm{m}$ in diam. Found in Czubrówka and Sanka streams.

In the K-CZU previously reported from the Szklarka stream (Amirowicz 1986). In Poland reported also from the salt marshes near Leczyca (Plinski 1973). The report of Gutwinski (1895) concerns the Ukraine (formerly Polish territory).

General distribution : Europe, Asia, North America, and North Africa; not common.

\subsection{Sectio Anomalae}

- Vaucheria canalicularis (L.) T. A. Christensen f. canalicularis $(=V$. woroniniana Heering $\mathrm{f}$. woroniniana), (Determination after Rieth 1980). Figs. 19-20, 25.

Vegetative filaments $57.5-86.6 \mu \mathrm{m}$ in diam. Monoecious. Oospores 67-102 $\mu \mathrm{m}$ in diam., $85-134 \mu \mathrm{m}$ long. Found in Czernka and Pokrzywianka streams.

In the K-CZU previously reported from Bolechowicki, Rudawa, Raclawka, Kobylanka, Pradnik and Dlubnia streams (Amirowicz 1986). In Poland reported also from the Rivers Warta and Widawka (ZelaznaWieczorek 1998).

General distribution : Europe, Asia, North America, North Africa ; common.

- Vaucheria debaryana Woronin f. debaryana $(=V$. cruciata (Vaucher) De Candolle), (Determination after Rieth 1980). Figs. 17-18, 26.

Vegetative filaments $19-30.4 \mu \mathrm{m}$ in diam. Monoecious. Oogonium spherical with small, short bill, $38,5-43,5 \mu \mathrm{m}$ in diam., $47-57 \mu \mathrm{m}$ long, usually placed 1-2 under antheridium, on long pedicel. Antheridium 13.3-17.1 $\mu \mathrm{m}$ in diam., opening with two pores, borne on tubular pedicel, narrower than the vegetative filaments. Found in the Kobylanka stream. 

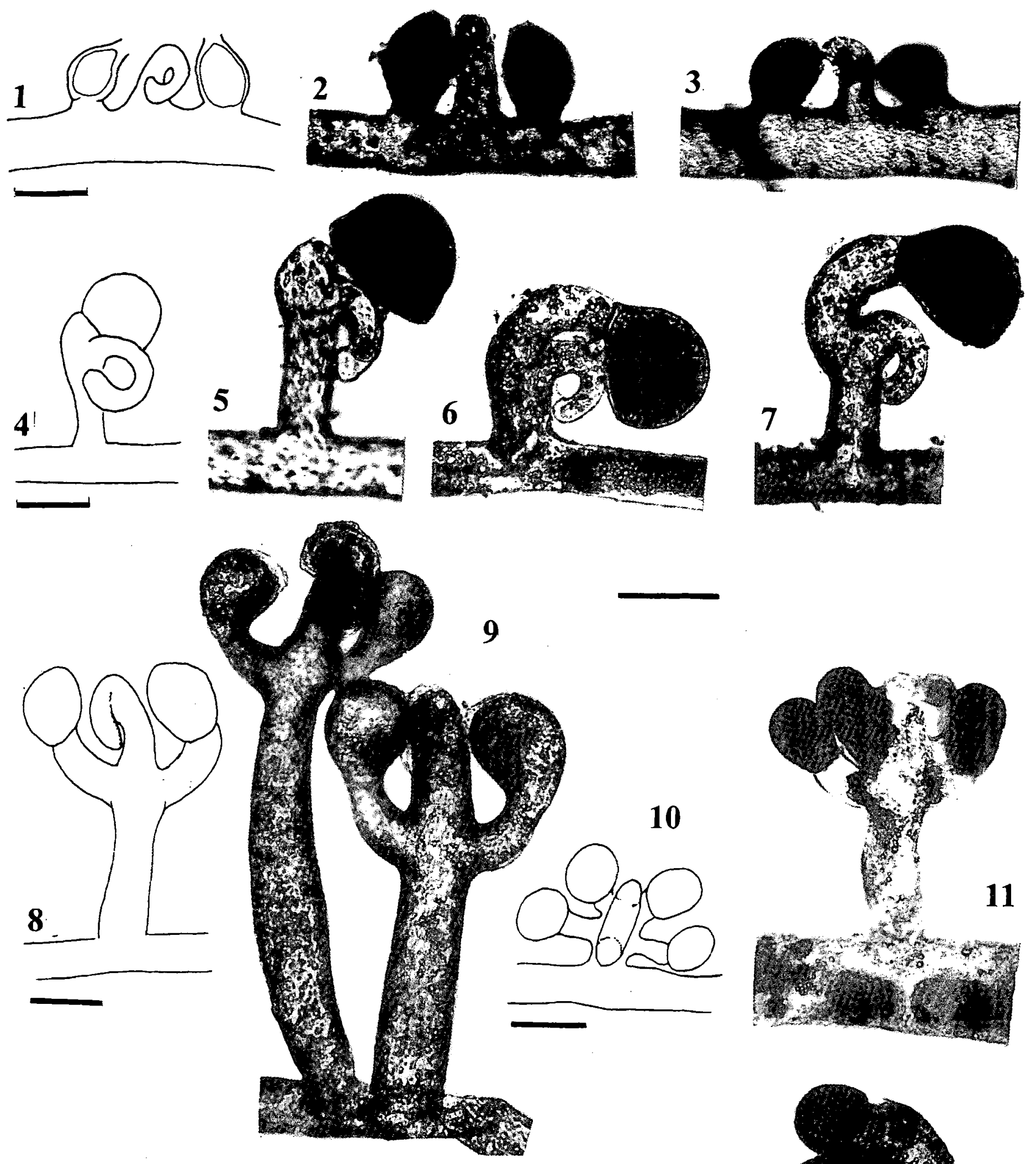

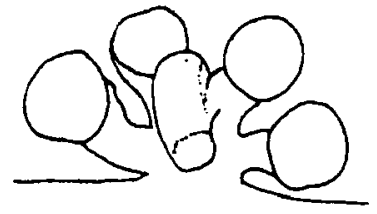

12

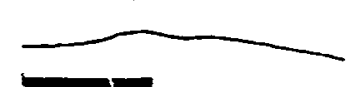

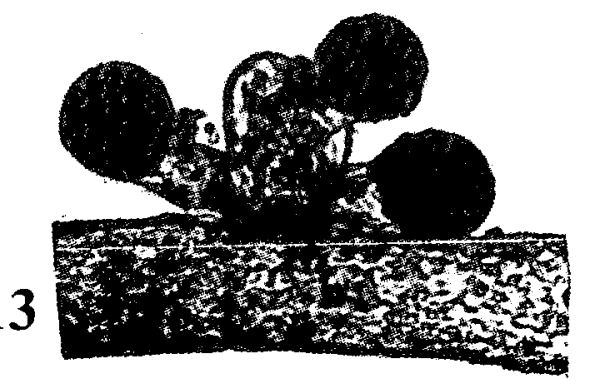
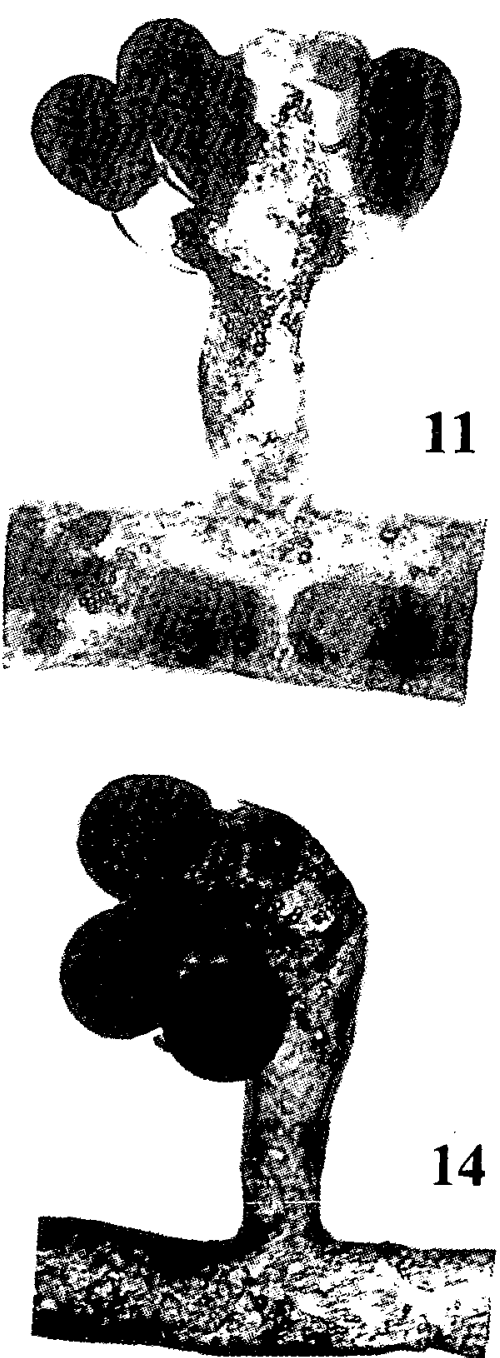

Figs. 1-14. Location of sexual organs of Vaucheria : 1-3. Vaucheria bursata ; 4-7. V. frigida ; 8-9 V. geminata ; 10-14. V. racemosa. Scale bar $=100 \mu \mathrm{m}$.

Figs. 1-14. Localisation des organes sexuels de Vaucheria : 1-3. Vaucheria bursata ; 4-7. V. frigida; 8-9 V. geminata; 10-14. V. racemosa. Echelles $=100 \mu \mathrm{m}$. 

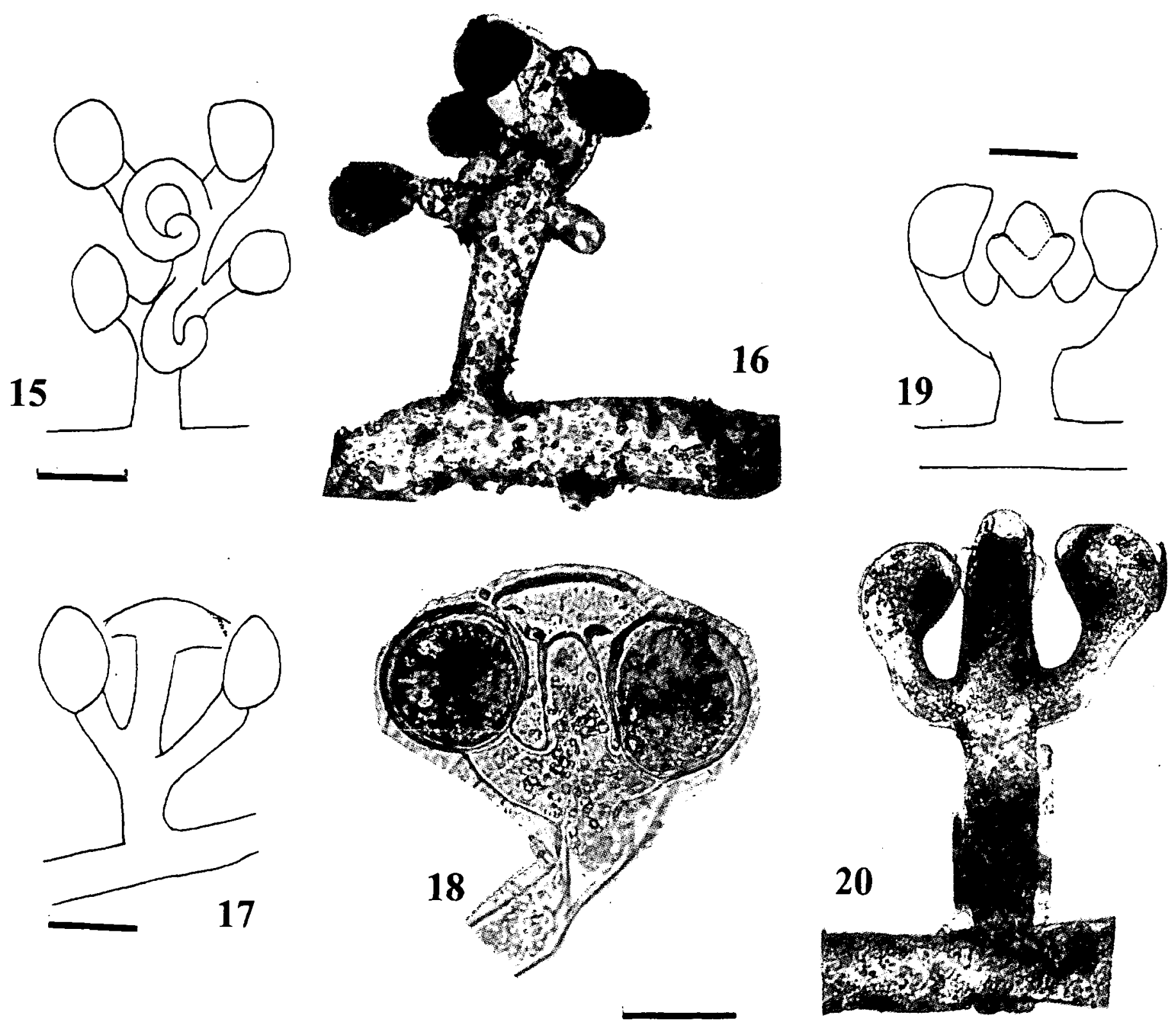

Figs. 15-20. Location of sexual organs of Vaucheria : 15-16. V. erythrospora ; 17-18. V. debaryana; 19-20. V. canalicularis. Scale bar $=100 \mu \mathrm{m}$.

Figs. 15-20. Localisation des organes sexuels de Vaucheria : 15-16. V. erythrospora ; 17-18. V. debaryana ; 19-20. V. canalicularis. Echelles $=100 \mu \mathrm{m}$.

In the K-CZU previously reported from the Raclawka and Pradnik streams (Amirowicz 1986).

General distribution : Europe, Asia and North Africa ; not common ; poor indicator of water quality (Sladecek \& Sladeckova 1996).

\section{Discusion}

Annual observations from October 1993 to November 1994 were made in the Kobylanka stream which forms part of the fluvial system of the River Rudawa, (a left-bank tributary of the Vistula) (Fig. 1). The stream is ca.. $7500 \mathrm{~m}$ long, its spring being situated at an altitude of ca. $309 \mathrm{~m}$; it flows among Jurassic stones of the valley and partly through the village Kobylany, among the village houses and also passing those of Witkowice, Zielona, and Zabierzów (Fig. 2).

V. canalicularis, V. debaryana, V. geminata, V. bursata, V. frigida, and V. racemosa were found on 10 sites in the Kobylanka stream. They occurred in different localities - at the spring (Site 1), on the surface of stones partly submerged, small, filamentous or thin mats were found but only in samples from November and December of 1993 and April, May, and June of 1994. The ones were recognized as V. bursata. In April it occurred together with $V$. racemosa and filaments of V. debaryana (Table 1). 


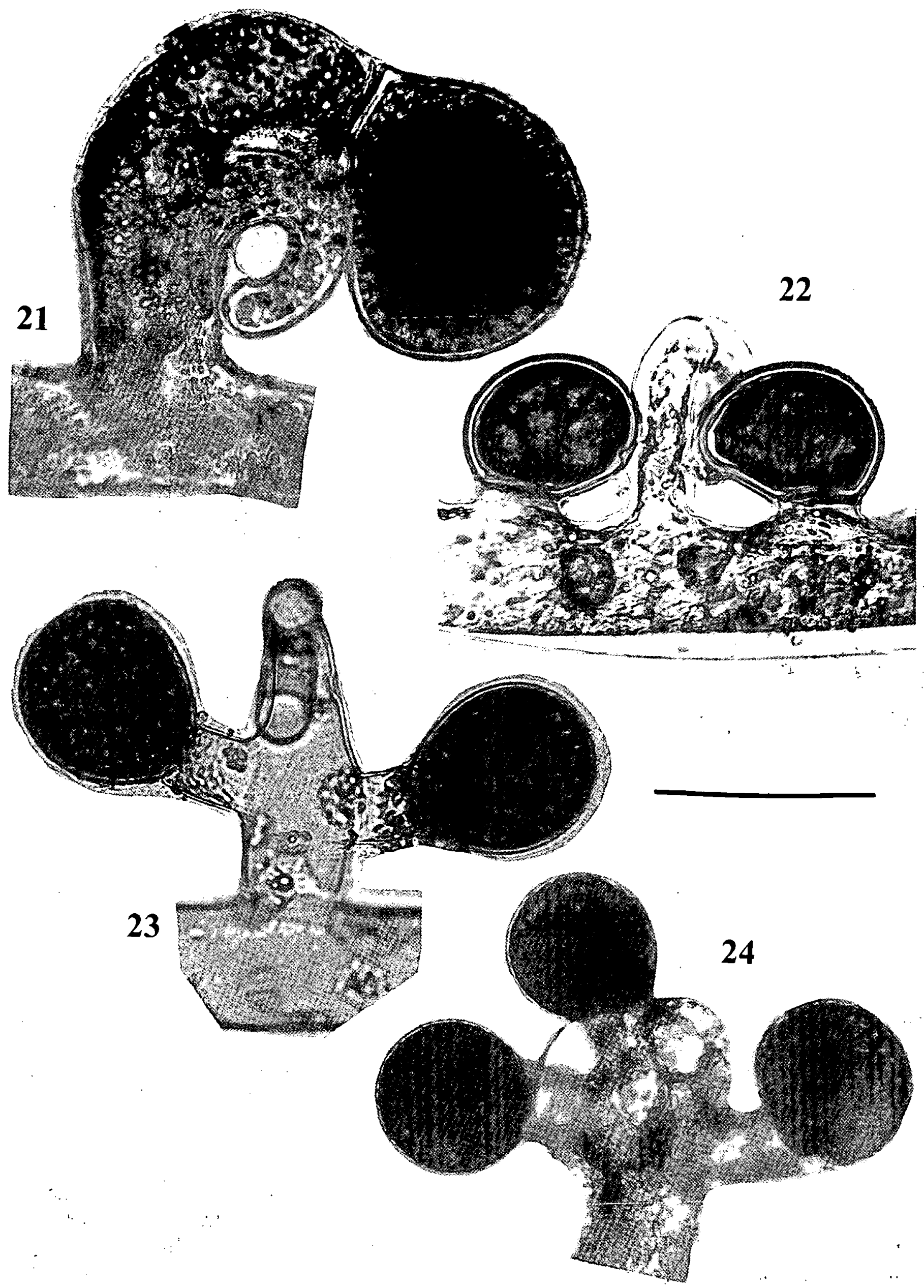

Figs. 21-24. Structural details of sexual organs of Vaucheria :21. V. frigida ;22. V. bursata ;23. V. geminata ; 24. V. racemosa. Scale bar $=100 \mu \mathrm{m}$.

Figs. 21-24. Détails des organes sexuels de Vaucheria : 21. V. frigida ; 22. V. bursata ;23. V. geminata ; 24. V. racemosa. Echelle $=100 \mu \mathrm{m}$. 


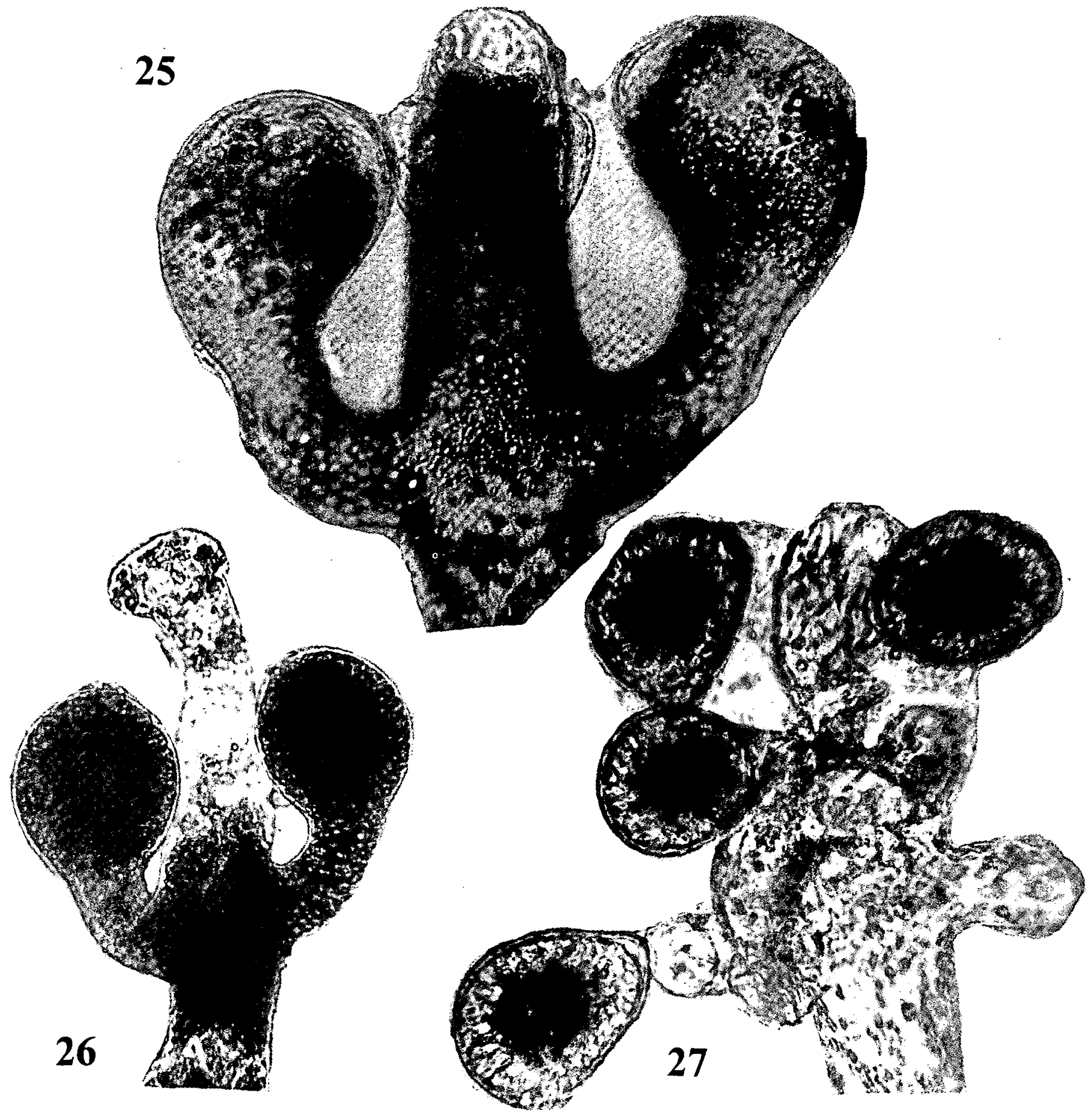

Figs. 25-27. Structural details of sexual organs of Vaucheria : 25. V. canicularis ; 26. V. debaryana; 27. V. erythrospora. Scale bar $=100 \mu \mathrm{m}$.

Figs. 25-27. Détails des organes sexuels de Vaucheria : 25. V. canicularis ; 26. V. debaryana ; 27. V. erythrospora. Echelle $=100 \mu \mathrm{m}$.

The surface of the wet mud at the bank of the stream, $10 \mathrm{~m}$ from the spring (Site 2), was covered with small mats or some filaments of $V$. frigida during October, and November 1993 and also in January, March, April and June 1994, but only in March were the mats large and $V$. frigida, $V$. bursata, and $V$. racemosa were recognized. In April among the medium mats were found $V$. frigida together with $V$. bursata. Velvety mats, part- ly submerged in water in the valley (Site 3), were observed in January and from March to May 1994, only $V$. bursata being built of it. In September 1994 also large mats were observed which consisted of $V$. bursata and $V$. canalicularis. Mats ca. $7 \mathrm{~cm}$ in diameter were found in part of a swift-flowing stream under the water and flood waters (Site 4). V. bursata were recognized on this site in November 1993 and in March, April, and 
June 1994. V. frigida also being the component of mats in March 1994. Near the inflow of streams from valley to village, close to the wooded thrashold (Site 5) and in $20 \mathrm{~cm}$ deep water on the surface of mud, mats 2.5-10 $\mathrm{cm}$ in diameter were observed, but in January, March, and April and from May to August 1994 they consisted of $V$. bursata. This taxon was also found in Kobylany village in a small branch of the main stream, flowing by a private house (Site 6 ).

On the surface of the mud they were growing as cotton-like pills $10 \mathrm{~cm}$ in diameter. The taxon was recognized in samples from October and November 1993, and from January to April when they grew together with $V$. geminata and from May to June 1994. Small mats, built of short, rigid filaments of Vaucheria species, covered surface of stones forming the village road (Site 7). In samples taken from this site were recognized : V. bursata and V. geminata in October, December 1993, in March, V. racemosa and bursata, while from April to August $1994 \mathrm{~V}$. bursata were noted. The same species also occurred at the concrete path of a private garden (Site 8).

Only a few specimens of $V$. geminata and $V$. bursata were found in small mats occurring at the bridge in the village Wieckowice (Site 9). Small mats were also found under the bridge on the surface of mud in Zielona village (Site 10) but species were not recognized.

$V$. canalicularis, V. bursata, V. verticillata, and $V$. racemosa ( $V$. racemosa) were previously recorded by Amirowicz (1983) from this stream but only $V$. verticillata was not found during this study.

Vaucheria species occurred in this stream throughout the year, only the areas of mats being changed : they were much smaller, and thinner during the winter than in the summer and their filaments were shorter. Identification of Vaucheria species was not made in all the collected samples because the sex organs cannot develop in every month (Table. I).

Throughout the year, the physico-chemical parameters of water in Kobylanka were rather stagnant. At Sites 1-5 (Fig. 2) the water was cool with a temperature averaging (3)-7-9(-11) ${ }^{\circ} \mathrm{C}$; the lowest temperatures were in the spring in March and the highest in April. The $\mathrm{pH}$ value was always alkaline 7.5-8.2(-8.5). The remaining parameters were e.g. total hardness (5.0-6.4 $\mathrm{mVal})$, carbonate hardness (4.0-5.2 mVal), Ca (86-120 $\mathrm{mg} / \mathrm{l}), \mathrm{Na}_{3} \mathrm{PO}_{4}$ (ca. $\left.18 \mathrm{ppm}\right), \mathrm{Cl}(20-58 \mathrm{mg} / \mathrm{l})$ and oxygen concentration which varied from 4 to10(13) $\mathrm{mgl} / \mathrm{l}$. The same parameters investigated on the other five sites (6-8 in Kobylany village, 9 in Wieckowice and 10 in Zielona) were minimally different from the first one
(1-5) : water temperature averaging $7-17^{\circ} \mathrm{C} ; \mathrm{pH}$ value was slightly higher varying from 7.9 to 8.5 ; the remaining parameters have had the same level.

In the material collected, during 1993-1998 from 35 sites situated in the K-CZU seven taxa : $V$. bursata, $V$. geminata, V. canalicularis, V. racemosa, V. erythrospora, $V$. frigida, and $V$. debaryana were identified. Moreover, from this area also V. undulata Jao, V. pseudogeminata Dang, V. prolifera Dang. and V. verticillata Kütz., were previously reported by Amirowicz (1986) while $V$. hamata, V. pachyderma were reported by Skalna (1973) and V. ornithocephala reported again by Waszkiewicz \& Zelazna-Wieczorek (1999). At present 14 taxa which occurred in the Kraków-Czestochowa Upland are known.

Most of the taxa occurred on the surface of stones, pieces of wood, at the rim of streams under the water and on wet soil. In all cases the water was well oxygenated and mats usually had periodic contact with the air. It was observed that the season of the year affected the size of mats growing on different surfaces : the smallest mats were observed during the winter, the largest in summer and the first part of autumn.

The $V$. bursata was observed in most of the examined localities (27). The species formed an abundant pulvinate or cottony agglomeration of thalli (very large mats, usually at the edge of shallow streams or in deep of water. V. bursata usually occurred with young filaments mixed of V. geminata with Cladophora glomerata. They occurred, both, in clean and polluted source parts of streams. These species have very large tolerance on pollutions; they are not good indicators of water pollution (Sladecek \& Sladeckova 1996).

$V$ geminata noted in 16 streams was accompanied by $V$. bursata and $V$. canalicularis. It was only once found as a single taxon in the Krztynia stream where it made small rough tufts. These two very common taxa, $V$. bursata and V. geminata, were found in well oxygenated places where the turbulation of water was strong and streams were polluted - records of mats about $1 \mathrm{~m}^{2}$ in size in the Saspówka stream near the beaver lodges.

$V$ racemosa occurred in slowly flowing parts of streams, and stagnant water (13 sites) usually with $V$. bursata sometimes among young filaments of Cladophora glomerata, which confirms the earlier observation of Zelazna-Wieczorek (1998). Also V. canalicularis occurred on 12 sites sometimes with V. geminata. $V$. frigida, and $V$. debaryana but were not common. $V$. hamata, prolifera, undulata, verticilata and ornithocephala were rarely noted on the $\mathrm{K}-\mathrm{CzU}$. These species were found in one place (Table 2). 
Table 1. Annual cycle of thalli of Vaucheria species occurring in the Kobylanka stream.

Tableau 1. Cycle annuel du thalle des espèces de Vaucheria présentes dans la rivière Kobylanka.

\begin{tabular}{|c|c|c|c|c|c|c|c|c|c|c|c|c|c|c|c|}
\hline \multicolumn{4}{|c|}{1993} & \multicolumn{12}{|c|}{1994} \\
\hline Sites & $\begin{array}{l}x \\
\stackrel{2}{\sim}\end{array}$ & 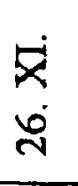 & $\begin{array}{l}\Xi \\
\vdots \\
\vdots\end{array}$ & $\vec{n}$ & $\begin{array}{l}\text { 具 } \\
\text { i }\end{array}$ & $\begin{array}{l}\Xi \\
\dot{\Xi} \\
\dot{m}\end{array}$ & $\begin{array}{l}\geq \\
\text { i }\end{array}$ & $\begin{array}{l}\vec{N} \\
\text { in }\end{array}$ & $\begin{array}{l}\dot{5} \\
\dot{N}\end{array}$ & $\begin{array}{l}\vec{j} \\
\dot{m}\end{array}$ & $\begin{array}{l}\text { 寻 } \\
\stackrel{\circ}{\circ}\end{array}$ & $\begin{array}{l}\underset{m}{0} \\
\stackrel{0}{\circ}\end{array}$ & $\begin{array}{l}x \\
2 \\
2\end{array}$ & $\begin{array}{l}\text { रें } \\
\text { ¿ें }\end{array}$ & $\begin{array}{l}\vec{\nabla} \\
\infty \\
\infty\end{array}$ \\
\hline 1 & 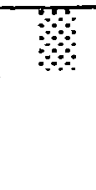 & $\begin{array}{l}3 \\
\mathbf{a}\end{array}$ & $\begin{array}{l}\mathbb{1} \\
\mathbf{a}\end{array}$ & $\|$ & 3 & 3 & $\begin{array}{c} \\
\mathbf{a} \mathbf{e} \\
\mathbf{f}\end{array}$ & $\mathbf{a}$ & a & W: & 3 & ? & 3 & $\|$ & $\|$ \\
\hline 2 & d & 8 & $\begin{array}{l}\| \\
\text { d }\end{array}$ & $\begin{array}{l}\| \\
d\end{array}$ & $\|$ & $\begin{array}{c}\mathbf{a d} \\
\mathbf{a} \mathbf{d}\end{array}$ & $\begin{array}{l}-3 \\
\mathbf{a}\end{array}$ & 3 & $\begin{array}{l}\| \\
\text { d }\end{array}$ & $\|$ & $\|$ & ? & 3 & 3 & $\|$ \\
\hline 3 & 3 & 3 & (") & a & 䐱 & a & $\mathbf{a}$ & 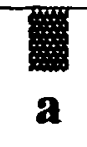 & 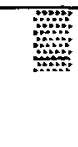 & 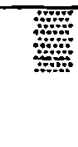 & 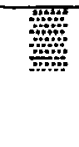 & ac & 3 & 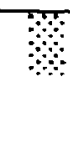 & 3 \\
\hline 4 & 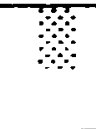 & $\begin{array}{l}\text { b } \\
\mathbf{a}\end{array}$ & 涪 & 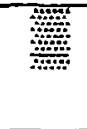 & 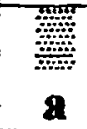 & $\mathbf{a d}$ & a & & $\frac{}{\mathbf{a}}$ & & 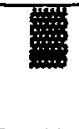 & 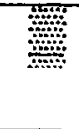 & 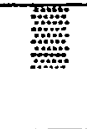 & wa & 涪 \\
\hline 5 & 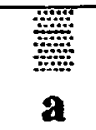 & 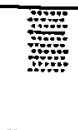 & $\equiv$ & $\frac{1}{\mathbf{a}}$ & a & 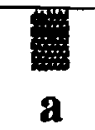 & & $\frac{}{\mathbf{a}}$ & 姃 & a & 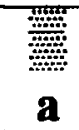 & $\frac{3.3}{3}$ & 潾 & (\$) & 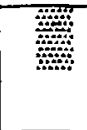 \\
\hline 6 & $\begin{array}{l}\text { a } \\
\mathbf{a}\end{array}$ & $\begin{array}{l}\text { a } \\
\mathbf{a}\end{array}$ & & & a & a & $\mathbf{a b}$ & $\mathbf{a}$ & $\mathbf{a}$ & & 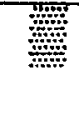 & 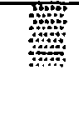 & \# & 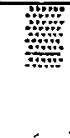 & 3 \\
\hline 7 & $\mathbf{a b}$ & 3 & $\begin{array}{c}\mathrm{b} \\
\mathbf{a t e}\end{array}$ & ? & $\begin{array}{l}\mathbf{a} \\
\mathbf{a}\end{array}$ & $\begin{array}{l}\text { a e } \\
\end{array}$ & $\begin{array}{l}\text { t } \\
\mathbf{a}\end{array}$ & $\begin{array}{l}\mathbf{a} \\
\mathbf{a}\end{array}$ & $\begin{array}{c}\text { e } \\
\mathbf{e}\end{array}$ & 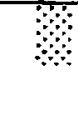 & $\begin{array}{l}\mathbf{a} \\
\mathbf{a}\end{array}$ & 3 & 3 & 8 & 3 \\
\hline 8 & 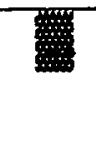 & $\frac{1}{\mathbf{a}}$ & 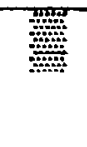 & 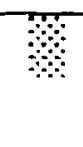 & $\begin{array}{l}\text { a } \\
\text { a }\end{array}$ & b c & a e & $\mathbf{a} \mathbf{b}$ & & & & & 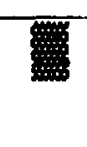 & (w) & 泣 \\
\hline 9 & $\prod_{\mathbf{b}}$ & $\|$ & $\mathbf{a} \mathbf{b}$ & 0 & 0 & $\begin{array}{l}\| \\
\mathbf{b}\end{array}$ & $\|$ & $\begin{array}{l}\| \\
\text { b }\end{array}$ & $\|_{\mathbf{b}}$ & $\|$ & $\|$ & $\|$ & 0 & 0 & 0 \\
\hline 10 & $\|$ & $\|$ & $\|$ & \| & $\|$ & 0 & $\|$ & $\|$ & $\|$ & $\|$ & $\|$ & $\|$ & $\|$ & 0 & 0 \\
\hline
\end{tabular}

Legends: - large mats (ca. 6-10 cm in diam., - small mats (ca. $1-2 \mathrm{~cm}$ in diam., $\|$ - filaments (ca. $0.5 \mathrm{~cm}$ in diam.), o - absent; recognized taxa: a $-V$. bursata, b-V. geminata, c $-V$. canalicularis, d - V. frigida $\mathbf{e}-V$. racemosa, $\mathbf{f}-V$. debaryana

Légendes: - grande natte (ca. $6-10 \mathrm{~cm}$ de diam., diamètre)., o - absent;

espèces: a $-V$. bursata, b-V. geminata, c $-V$. canalicularis, d $-V$. frigida $\mathbf{e}-V$. racemosa, $\mathbf{f}-V$. debaryana 
Table 2. Vaucheria species reported from the Krakow-Czestochowa Upland.

Tableau 2. Espèces de Vaucheria recensées dans la région du plateau de Cracovie-Czestochava.

\begin{tabular}{|c|c|c|c|c|c|c|c|c|c|c|c|c|c|c|c|}
\hline Sites & 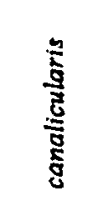 & $\begin{array}{l}\text { gू } \\
\text { है } \\
\text { ชึ } \\
\text { ชึ }\end{array}$ & 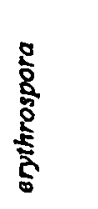 & 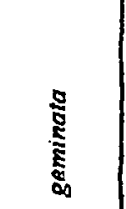 & $\begin{array}{l}\mathrm{g} \\
\stackrel{\mathrm{E}}{\mathbf{g}}\end{array}$ & 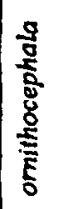 & $\begin{array}{l}\text { है } \\
\text { है } \\
\text { है } \\
\text { है }\end{array}$ & 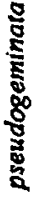 & 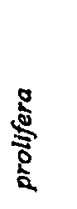 & $\begin{array}{l}\text { 몿 } \\
\text { : } \\
\text { : }\end{array}$ & $\frac{g}{8}$ & $\begin{array}{l}\mathrm{g} \\
\frac{\mathrm{s}}{5} \\
\mathrm{~s}\end{array}$ & 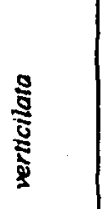 & 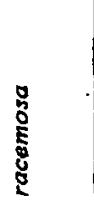 & 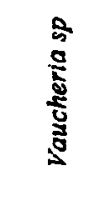 \\
\hline \multicolumn{16}{|c|}{ Springs } \\
\hline Kobylany & & & & & & & & & & $\boldsymbol{A}$ & & & & $\pi$ & \\
\hline Mst6w & & & & & & - & & & & & & & & & \\
\hline \multicolumn{16}{|c|}{ Streams } \\
\hline Beqdionido & & & & - & & & & & & - & & & & 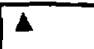 & \\
\hline Biahucha & & & & & & & & & & $a$ & & & & & \\
\hline Bhah Przemsza & \pm & & & & & & & & & $e$ & & & & & \\
\hline Botechowicld & $\Delta$ & & & & & & & & & $\Delta$ & & & & & \\
\hline Brymia & & & & \pm & & & & & & $n$ & & & & & \\
\hline Centurta & & & & & & & & & & E & & & & & E \\
\hline Cernka & a & & & a & & 5 & & & & 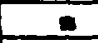 & & & & 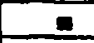 & \\
\hline Caubróntes & & & \pm & - & & & & & & $\square$ & & & & & \\
\hline Dhuhnta & \pm & & & & & & & & & 4 & 4 & & & 4 & \pm \\
\hline Dulburlon & & & & $\square$ & & & 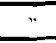 & & & 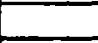 & & & & & \\
\hline Flasabrika & & & & 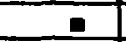 & & & & & & $\square$ & & & & & \\
\hline Fripópwin & & $\therefore$ & & $\square$ & & & & & & 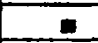 & & & & \pm & \\
\hline Garticalea & & & & $\Delta$ & & & & & & - & & & & 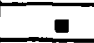 & \\
\hline Klacawoda & & & & $\pi$ & & & & & & $=$ & $=$ & & & & \\
\hline Kobylanka & $\Lambda$ & - & & $a$ & & & & & & $4=$ & E- & & 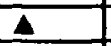 & $\triangle 1$ & \\
\hline \multicolumn{16}{|l|}{ Kobytica } \\
\hline Krzeszóphe & & & & 8 & & & & & & 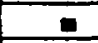 & & & &. & \\
\hline Kratymia & & & & $=-1$ & & & & & & & & & & & \pm \\
\hline Mietoinks & & & & & & & & & & & & & & & 0 \\
\hline Pilica & & & & & & & & & & $\square$ & & & & & 4. \\
\hline Polozy timla & & & & & & & & & & & & & & & 1 \\
\hline Pradnilk & $n$ & 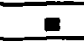 & & & & & & & & $\Delta$. & $\Delta$ & & & $\Delta$ & $\Delta=$ \\
\hline Rachawla & $\Delta \ldots$ & $\Delta$ & & & & & & & & $\Delta$ & $\overline{4}$ & & & & \\
\hline Rudama & 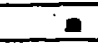 & & & & & & & & & $\Delta=$ & & & & $\Delta$ & \\
\hline Sanka & & & E & & & & & & ? & & 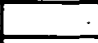 & & & & \\
\hline Saspowioa & & & & - & & & & & & 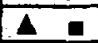 & & & & - & $\Delta$ \\
\hline Staninks & $\boldsymbol{\Delta}$ & & & & & & & $\Delta$ & $\Delta$ & $\Delta$ & & $\Delta$ & & & \\
\hline Smolnnits & $\Delta$ & 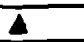 & & & & & & & & 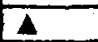 & & & & $\Delta$ & \\
\hline Surenionga & $\boldsymbol{\Lambda}$ & & & & & & $=$ & & & & & & & & \\
\hline Syldarka & & & & - & $\triangle$ & & & & & $\Delta$ & & & & $\ldots$ & \\
\hline Wiercica & & & & & & & & & & $=$ & & & 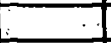 & - &.$\quad$. \\
\hline \multicolumn{16}{|l|}{ Wodonka } \\
\hline \multicolumn{16}{|l|}{ Zebrónke } \\
\hline Vistula River & $\bar{\Lambda}$ & & & 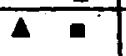 & & & & $\bar{\Delta}$ & & 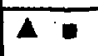 & 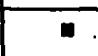 & $\bar{\Lambda}$ & . & & $\Delta \because$ \\
\hline \multicolumn{16}{|c|}{ Ponds in: } \\
\hline Wronisld & & & & & & & & & & - & & $\therefore$ & E & a & \\
\hline Khucrech & & & & n & & & & & & & & & & 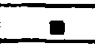 & \\
\hline \multicolumn{16}{|l|}{ Jaworanik - } \\
\hline Shamosxyce & & & & & & & & & & & & & & $=$ & \\
\hline \multicolumn{16}{|l|}{ Wolbrom - } \\
\hline Soll fim Prisy & & & & & & & $\Delta$ & & 7 & & & & 9 & & \\
\hline
\end{tabular}

( - previous data, données antérieures; a - data of this study, données présentes, - absent )

According to Amirowicz (1986), Vaucheria species prefer clean water. They occurred in oligosaprobic or betamesosaprobic zones. After a year long observation of Vaucheria in the Kobylanka stream it was recognized that the level of oxygenation of the water and possibility of contact with the air of part of the mats are very important factors. The rare occurrence of speci- mens in the investigated ponds in the Jurassic Landscape Park is connected with the higher temperature of the water and poor oxygenation, which limited their development.

The described taxa of Vaucheria were usually found 'in the company of filamentous green algae such as Cladophora glomerata (L.). Kützing var. glomerata, 
Ulothrix tenuissima Kützing, Tetraspora sp. and xanthophycean Tribonema viride Pascher.

Mats of Vaucheria have an important ecological value because they provide the substrate for epiphytic diatoms which are the food of numerous crustaceans e.g. Gammarus ; they, in turn, are food for trouts. According to Professor Jadwiga Sieminska, during the sixties of the last century the belts $(20-30 \mathrm{~cm})$ of Vaucheria species occurred along tens of metres on muddy bottom streams. This she had observed since the 1930s. In her opinion, during the eighties the water levels in streams fell (because of construction of watersworks) and the mats of Vaucheria decreased.

\section{Acknowledgments}

The author is grateful to Professor Jadwiga Sieminska for her kind assistance during the elaboration of this paper and Mrs. Strelley Acheson-Waligorska for polishing the English version of this work.

This work was supported by grant no. 6.P204 044 from the State Committee For Scientific Research (KBN).

\section{References}

Amirowicz A. 1981a. - The natural environment of the Bolechowicki Stream and the problems connected with its protection. Chronmy Przyr. Ojcz., 37 (5) : 17-24.

Amirowicz A. 1981b. - Vaucheria canalicularis (L.) Christensen 1968 from the Bolechowicki Stream near Cracow (Southern Poland). Fragm. Flor. Geobt., 26 (2-4) : 354-362.

Amirowicz A. 1983:-...Macroscopic algae from the Bolechowicki Stream (Cracow-Czestochowa Upland, Southern Poland): Fragm.-Flor-Geobot.; 27 (4) : 667:675.

Amirowicz-A. 1986. - Vaucheria species in the neighbourhood of "Cracow. Fragm. Flor. Geobot., 29 (3-4): 465-475.

Christensen T. 1956. - Studies on the genus Vaucheria III. Remarks on some species from breckish water. Botaniska Notiser, 109 (2):275-280.

Christensen T. 1969. - Vaucheria collections from Vaucher's Region. Biol. Skr. Vid. Selsk., 16 (4) :1-35.

Christensen T. 1973. - Some early Vaucheria descriptions. Bot. Notiser, $126: 513-518$.

Christiansen T. 1987. - Seaweeds of the British Isles. Tribophyceae (Xanthophyceae). London, British Museum (Natural History); V4 : 34 p.

Dratnal E. 1977. - Biologia wód Ojcowskiego Parku Narodowego - [Biology of the water in the Ojców National Park]. Przyroda Ojcowskiego Parku Narodowego. Studia Naturae, Ser. B. 28 : 371-403, (in Polish).

Gutwinski R. 1884. - Materialy do Flory wódorostów Galicji. [Materials to the Galician flora of algae.]. Spraw. Komis. Fizjogr., 18 (2) : 127-138. (in Polish).

Gutwinski R. 1890. - Materyaly do flory glonów Galicyi. Czesc II. [Materials to the Galician flora of algae. Part II] - Spraw. Komis. Fizjogr, $25: 1-43$, (in Polish).
Gutwinski R. 1895. - Prodromus florae algarum galiciensis. Rozpr. Akad. Umiej., Wydz. Mat.-Przyr., 28 : 274-449.

Kadlubowska J. Z. 1964. - Diatoms of the river Pilica and their importance in the water pollution evaluation. Part II. Microflora of the river Pilica. Zesz. Nauk. Uniw. Lódzk., Nauki Mat.-Przyr., Ser. II, $16: 93-150$. (in Polish with English summary).

Mrozinska T. 1957. — Fadenalgen, die auf der Oberfläche der höheren Wasserpflanzen in der Versuchsteichwirtschaft Ocháby vorkomen. Fragm. Flor. et Geobot., $3: 141-152$.

Nawrat B. 1993. - Automn-winter diatoms attached to Vaucheria filaments in Kluczwoda stream near Cracow. Fragm. Flor. Geobot., 38 (2) : 715-736, (in Polish with English summary).

Plinski M. 1973. - The algae of salt marshes near Leczyca, Central Poland. - Monogr. Bot., 39 : 3-88, (in Polish with English summary).

Rieth A. 1980. - Xanthophyceae. 2 Teil. H. Ettl J. Gerloff \& H. Heynig (eds), Süsswasserflora von Mitteleuropa. Gustav Fischer Verlag, Jena, $4: 147$ p.

Siedlecka-Binder Z. 1967. - La végétation des macrophytes dans les torrents du Parc National d'Ojców. - Chrronmy Przyr., 32 : 171-206. (in Polish with French summary).

Skalna E. 1973. - The algae of the karst vaucluse spring at Jerzmanowice (Cracow-Czestochowa Jurassic region). Fragm. Florist. Geobot., 19 (3) : 343-348. (in Polish with English summary).

Skalna E. 1979. - Soil algae occurring in vegetable cultivations at Prusy near Kraków - Fragm. Florist. Geobot., 25 (4) : 607-648.

Sladecek V. \& Sladeckova A. 1996. - Atlas of aquatic organisms with respect to the water supply, surface waters and wastewater treatment plants. Part. I., Praha. Ceská vedeckotechnická vodohospodárská spolecnost : $351 \mathrm{p}$.

Starmach K. 1939. - Über einen Fall der Neustonfärbung in einen Teiche der Fischereiversuchsstation in Mydlniki bei Kraków. Acta Soc. Bot. Polon., 16 (2) : 127-152. (in Polish with German summary).

Stârmä̈h K. 1972. - Zielenice nitkowate. Chlorophyta. 3. Flora Slodkowodna Polski, Warszawa-Kraków, PWN. (in Polish) : 10 : $750 \mathrm{p}$.

-Turoboyski L. 1956. - Pollution and ability of selft-purification of

.... the river Vistula in the section from 0 to $224 \mathrm{~km}$. - Gaz Woda Techn: Sanit., 30 (6) : 207-212. (in Polish).

Uherkovich G. 1970. - Über das Wisla-Phytoseston zwischen Kraków und Tczew. Acta Hydrobiol., 12, 2-3: 161-190.

Waszkiewicz D. \& J. Zelazna-Wieczorek. 1999. - The second discovery of Vaucheria ornithocephala (Xanthophyceae) in Poland. Fragm. Flor. Geobot., 44 (1) : 202-204.

Wolowski K. 1992. - First record of Vaucheria species (Xanthophyceae, Vaucheriaceae) from the gorge of Kluczwoda in southern Poland. Fragm. Flor. Geobot., 37 (2) : 535-538.

Wolowski K. 2001. - Advancement of studies on the algae of the Kraków-Czestochoa Upland, In : Partyka J. (Ed), Badania naukowe poludniowej czesci Wyzyny Krakowsko-Czestochowskiej, Ojców 2001 : 224-228.(in Polish )

Zelazna-Wieczorek J. 1998. - Taksony rodzaju Vaucheria De Candolle z Parku Krajobrazowego Miedzyrzecza Warty i Widawki. W : Materialy z XVII Sympozjum Sekcji Fykologicznej PTB, Glony jako uniwersalne bioindykatory degradacji srodowiska przyrodniczego ze szczególnym uwzglednieniem estuarium Odry. Szczecin-Lukecin 7-11 maja 1998: 59, (in Polish). 